\title{
Is There any Association between Blood Pressure and Education Level? the CroHort Study
}

\author{
Marijan Erceg$^{1}$, Ana Ivičević-Uhernik ${ }^{1}$, Josipa Kern ${ }^{2}$ and Silvije Vuletić ${ }^{2}$ \\ ${ }^{1}$ Croatian National Institute of Public Health, Zagreb, Croatia \\ ${ }^{2}$ University of Zagreb, School of Medicine, »Andrija Štampar« School of Public Health, Zagreb, Croatia
}

\begin{abstract}
A B S T R A C T
The aim of this study was to explore how the association of 5-year cumulative incidence of arterial hypertension (further 5-CIAH) and education varies according to body weight, age and sex. The study was conducted on cohort of 1383 subjects aged 18+ with initially normal blood pressure (systolic $<140 \mathrm{mmHg}$ and diastolic $<90 \mathrm{mmHg}$, and not taking medication). Data were collected in 2003 and repeated in 2008. Methods of descriptive statistics, $\chi^{2}$ test and logistic regression were used. No association between education level and hypertension development was recorded in the group of men and in the group of woman aged 65+. In the group of women with normal body weight, younger than 65 years, significantly higher 5-CIAH values were recorded in those with less than 12 years of education (32.5\% [22.0 to 42.9]) compared to those with 12 or more years of education (9.6\% [6.1 to 13.1]).
\end{abstract}

Key words: hypertension, cumulative incidence, education, CroHort study

\section{Introduction}

Essential hypertension remains a major modifiable risk factor for cardiovascular disease (CVD), which could be added to the public health list of neglected diseases despite the availability of effective primary and secondary prevention and treatment strategies ${ }^{1}$. Essential hypertension, which accounts for $95 \%$ of all cases, is a heterogeneous disorder which could be divided into various syndroms ${ }^{2}$. Factors that increase blood pressure (BP) have inherited, behavioral, and environmental components. BP variability attributed to all genetic factors varies from $25 \%$ in pedigree studies to $65 \%$ in twin studies, but the genetic alterations responsible for hypertension remain largely unknown ${ }^{3}$. What is known today is the number of risk factors including obesity, insulin resistance, high alcohol intake, high salt intake (in salt-sensitive patients), aging and sedentary lifestyle, stress, low potassium intake, and low calcium intake ${ }^{4,5}$. Furthermore, certain interactions between genetic and behavioral risk factors influence BP increase, as in a social environment which on its own is a major determinant of health ${ }^{6}$. Socioeconomic status measured from a social position and lifestyle can explain ill health, but psychosocial factors, such as a sense of isolation, deprivation or loss of control, are also important ${ }^{7}$. Although studies have shown that individuals with a lower socioeconomic status are more likely to develop CVD than are individuals with higher socioeconomic status, few have investigated the association between hypertension incidence and education or other indicators of socioeconomic status ${ }^{8-10} \mathrm{Sev}$ eral studies found that hypertension incidence was inversely associated with social class as measured by education and occupation ${ }^{8,10}$. A study of inner-city Blacks found that hypertension incidence was associated with income but not with education or occupation ${ }^{9}$. The First National Health and Nutrition Examination Survey (NHANES) found that hypertension incidence was higher among men who came from lower occupational classes or those who moved to lower occupational classes than among their counterparts ${ }^{11}$. A significant bivariate association between the incidence of hypertension and educational attainment has been found only among White women ${ }^{12}$. Further NHANES I studies demonstrated a significant interaction between age and education with an independent association between education and hypertension incidence among younger (25-44) but not older non-Hispanic White men and women ${ }^{13}$. These studies used more lenient criteria to define hypertension (systolic pressure $\geq 160 \mathrm{mmHg}$ and diastolic blood pressure $\geq 95 \mathrm{mmHg}$ ) 
than are the criteria provided presently by JNC- $7^{1}$, which is why initially normotensive group also included subjects who should have been classified in the group of hypertensive patients. This has affected the measured values of the incidence and associated risks.

The aim of the present study was to explore the association of educational attainment and incidence of hypertension among initially normotensive men and women according to JNC-7 criteria ${ }^{1}$.

\section{Methods}

The paper analyzes the data collected in the Croatian Adult Health Cohort Study (CroHort) project of the Ministry of Science, Education and Sport, No. 108-1080135-0264, started in 2003 and finished in 2008. The methodology of the CroHort, as a tool for monitoring risk factors for cardiovascular diseases, was described in a special paper in the latest issue ${ }^{14}$. Answers and measurements were collected for 1383 respondents (396 males and 987 females) who fulfilled initial inclusion criteria $(\mathrm{SBP}<140 \mathrm{mmHg}$ and $\mathrm{DBP}<90 \mathrm{mmHg}$ and not using antihypertension medication statement).

Data was collected by visiting nurses in form of a structured questionnaire, which, among other things, included anthropometric measurements (height, weight and blood pressure), questions on taking medication and education. Arterial pressure was measured by a calibrated mercury sphygmomanometer, which uses a standard cuff. Measurements were done in respondents' homes, in a sitting position. Values were read twice in intervals of 20 minutes or longer, and used to compute the average for every respondent.

The criteria for including respondents in the $\mathrm{JNC}-7^{1}$ group of hypertensive subjects were $\mathrm{SBP} \geq 140 \mathrm{mmHg}$ and/or DBP $\geq 90 \mathrm{mmHg}$ and/or usage of antihypertensive drugs statement. The criterion for including respondents in the overweight group was BMI in a range of 25-29.9 $\mathrm{kg} / \mathrm{m}^{2}$ and $\mathrm{BMI} \geq 30 \mathrm{~kg} / \mathrm{m}^{2}$ in the obese group.

Educational attainment at baseline was measured as the highest completed grade of school and categorized as less than 12 years and 12 and more years.

The paper shows analytic results expressed in percentages of the 5-year cumulative incidence of $\mathrm{AH}$ (further 5-CIAH), their 95\% confidence intervals (hereinafter $95 \% \mathrm{CI}$ or [ ]). Chi-square test and logistic regression statistical method were used with $\mathrm{p}=0.05$ as a cut-off value.

Separate analyses were performed for men and woman, and age groups 18-64 and 65+. Data processing was performed using the SPSS statistical package.

\section{Results}

In the group of 1383 subjects with initially normal blood pressure, $458(33.1 \%)$ had less than 12 years of education, while 924 (66.9\%) had 12 and more years. Significant differences in education have been recorded according to age and sex. The proportion of those with lower education was significantly lower at age 18-64 (27.3\%) compared to the $64.2 \%$ at age 65 and older $\left(\chi^{2}=112.8\right.$; $\mathrm{p}<0.05)$. In the group of women, there were significantly more subjects with lower education $(35.9 \%)$ than men $(26.3 \%)\left(\chi^{2}=11.58 ; \mathrm{p}<0.05\right)$. Subjects with 12 or fewer years of education were significantly more numerous in the group of women aged $0-64(29.7 \%)$ than men $(20.9 \%)$ of the same age $\left(\chi^{2}=8.807 ; \mathrm{p}<0.05\right)$. There were more women with less than 12 years of education $(75.4 \%)$ in the $65+$ age group than men $(46.4 \%(46.4 \%)$ of the same age $\left(\chi^{2}=18.82 ; \mathrm{p}<0.05\right)$. In the group of respondents with lower education, overweight subjects were significantly more numerous $(59.8 \%)$ compared to the group of more educated respondents $(45.9 \%)\left(\chi^{2}=23.36 ; \mathrm{p}<0.05\right)$. In the male group, there were no differences in education in relation to body mass index. In women, there was a significantly higher proportion of overweight (39.4\%) subjects with lower education, compared to those with normal body weight $(21.5 \%)\left(\chi^{2}=32.15 ; \mathrm{p}<0.05\right)$.

More men with lower education (38.5\% [29.1 to 47.8]) developed arterial hypertension compared to those with higher education (36.1\% [ 30.6 to 41.6]), but due to overlapping of their $95 \%$ confidence intervals, this difference was not statistically significant (Figure 1). In the group of women, 5-CIAH was significantly higher in respondents with lower education (44.6\% [39.5 to 49.8]) compared to those with higher educational attainment (26.5\% [23.1 to 30.0]) (Figure 1).

Significantly lower age-specific 5-CIAH was recorded in the group of men younger than 65 years $(30.9 \%$ [ 25.7 to 36.0]) compared to older age (58.3\% [47.8 to 68.9]). Within the observed age groups, no significant differences in 5-CIAH were recorded in relation to education (Figure 2). In the female group, significantly lower values of 5-CIAH were recorded in the younger age group (29.5\% [26.5 to 32.6]) compared to those aged 65 and older (56.0\% [47.6-64.4]). There was a significantly higher value of 5-CIAH in women younger than 65 with less education (39.5\% [33.5 to 45.6]) than those with more advanced education (25.3\% [21.9 to 28.8]) (Figure 2). In women aged 65 and over, no significant differences in 5 -CIAH in relation to education were noticed (Figure 2).

For women younger than 65 years, an analysis covering BMI value was performed. In the group of women under 65 , lower values of 5-CIAH were recorded among sub-

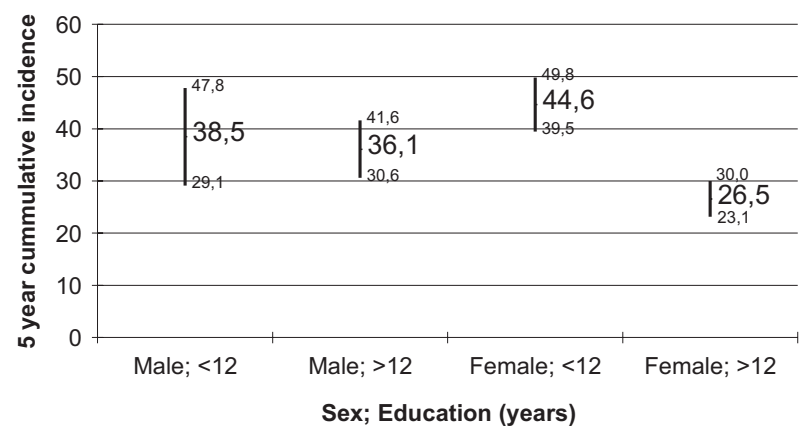

Fig. 1. Arterial hypertension, 5-year cumulative incidence in cohort by education and sex. 


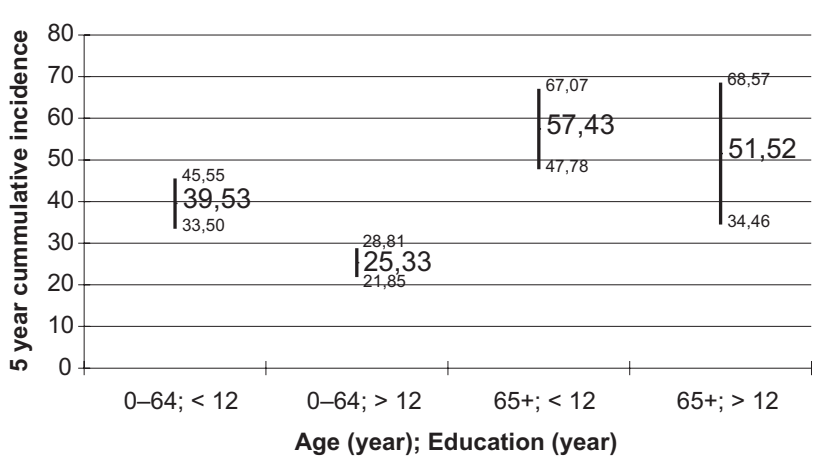

Fig. 2. Arterial hypertension, 5-year cumulative incidence in cohort of women by education and sex.

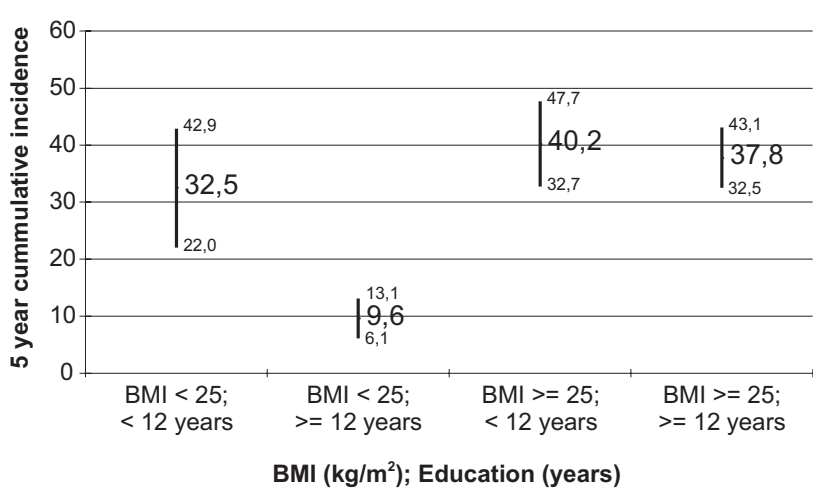

Fig. 3. Arterial hypertension, 5-year cumulative incidence in cohort of women aged 19-64 by education and body mass index (BMI).

jects with normal weight (14.6\% [10.9 to 18.3]) compared to those with overweight (38.6\% [34.3 to 42.9]). In the group of women with normal body weight and younger than 65 , significantly higher 5-CIAH values were recorded in those with less than 12 years of education (32.5\% [22.0 to 42.9$]$ ), as opposed to those with 12 or more years of education (9.6\% [6.1 to 13.1]). In the group of overweight women, younger than 65 , no significant differences in the development of arterial hypertension, in relation to the years of education, were recorded (Figure 3).

Unconditional multivariate logistic regression was performed using hypertension at the end of the follow-up as a criterion variable, while age, sex, body mass index and education attainment recorded at the beginning of the follow-up served as a predictor. Data for 1378 subjects was analyzed and the predictor of hypertension at the end of the follow-up were BMI, age and education (Figure 4). Age $(\mathrm{OR}=2.52)$ and overweight $(\mathrm{OR}=1.70)$ of subjects contributed most to the hypertension development. Arterial hypertension was significantly less common in subjects with 12 or more years of education $(\mathrm{OR}=0.74)$ compared to those with less than 12 years of education (Table 1). No significant contribution of sex to hypertension development was documented.

\section{Discussion and Conclusion}

The results of this study confirm the association between lower levels of education with a higher incidence of $\mathrm{AH}$ in a cohort of women, while in men the difference was not statistically significant. In women, this difference still remained when age and body weight of subjects were included in the analysis. In women of normal weight and aged 45-64, there was a significantly higher 5-CIAH among respondents with less than 12 years of education. The results of this study are consistent with the findings of research conducted in the USA establishing a correlation between the development of arterial hypertension and education in a group of non-Hispanic women of a younger age ${ }^{12}$. The results of this research did not link the level of education and development of $\mathrm{AH}$ in a group of men of younger age, unlike certain studies conducted in the United States ${ }^{13}$. One possible reason lies in the fact that in this study more stringent JNC-7 criteria were applied, according to which the group of hypertensive patients included respondents categorized elsewhere as having normal blood pressure, which could certainly have affected the measured values of the incidence and associated risk factors for the group of men ${ }^{12-13}$.

In the study of active working population cohort in France, a higher level of prevalence of hypertension adjusted to age and body mass index were observed in women with lower education. In subjects with a lower level of education who work at lower-ranked jobs, poorer levels of hypertension control have also been reported ${ }^{15}$.

In this study, the group of men showed no differences in the development of $\mathrm{AH}$ in relation to education. This, in part, may explain the low number of males in the cohort, but also a different perception of the impact of education on social status (SES) between men and women. To assess the association of SES and the development of

TABLE 1

RESULTS OF LOGISTIC REGRESSION ANALYSIS

\begin{tabular}{|c|c|c|c|c|c|c|c|}
\hline Term & Odds Ratio & $95 \%$ & C.I. & Coefficient & S. E. & Z-Statistic & P-Value \\
\hline Sex & 0.9368 & 0.7237 & 1.2126 & -0.0653 & 0.1317 & -0.4960 & 0.6199 \\
\hline Age & 2.5217 & 1.8386 & 3.4584 & 0.9249 & 0.1612 & 5.7388 & 0.0000 \\
\hline Education & 0.7431 & 0.5757 & 0.9590 & -0.2970 & 0.1302 & -2.2813 & 0.0225 \\
\hline BMI & 1.7036 & 1.4456 & 2.0076 & 0.5327 & 0.0838 & 6.3590 & 0.0000 \\
\hline CONSTANT & $*$ & $*$ & $*$ & -2.0361 & 0.4652 & -4.3764 & 0.0000 \\
\hline
\end{tabular}

$\mathrm{BMI}=$ body mass index 
hypertension in men, professional position, rather than the level of education, might be a more suitable indicator for use ${ }^{11}$.

According to the results of this study, differences in education in the oldest group of respondents did not affect the development of arterial hypertension. The recorded results can be explained by the fact that the oldest age group had a significantly higher proportion of respondents with lower education, which doubtlessly affected the perception of social inequalities in different generations caused by lower education. The USA study has also shown no effects of any differences in the level of education on the development of arterial hypertension in old age ${ }^{11}$.

Results of the research show that psychosocial factors are important determinants of population health. The accumulation of psychosocial experiences beginning in infancy and continuing throughout the life course, causing stress, seems to have biological effects on the development of degenerative diseases. Neuroendocrine stress mechanisms may contribute in particular to social gradients in risk of coronary disease and morbidity associated with reduced immunity. The observed social distribution of chronic diseases presents a challenge as the underlying pathophysiological processes, which take place over many years and involve many body systems, are incompletely understood. The biological perspective does not detract from the primary importance of social organization in generating health inequalities, but it can rather provide an approach to determining the specific aspects of the psychosocial environment that influence health ${ }^{16}$.

Influence of social factors in developing programs of primary and secondary prevention of arterial hypertension should be considered. Highly educated and socially better-off subgroups benefit more from innovations in medical care, they are also better educated to respond quickly to public health messages and policies than socially disadvantaged groups ${ }^{17}$. Hence, population-based interventions aimed at increasing physical activity and promoting healthy eating that fail to give due attention to differential response capabilities by socioeconomic position and geographical location and community-level resources to support healthy living may inadvertently contribute to an increase in health disparities even as overall population health improves ${ }^{18}$.

\section{Acknowledgements}

This article was prepared as a part of scientific project »Regionalism of cardiovascular behavioural risk factors model of intervention " (108-1080135-0264) supported by Ministry of Science, Education and Sport of the Republic of Croatia.

\section{R E F E R E N C E S}

1. CHOBANIAN A V., BAKRIS G L., BLACK H R, ET ALL, JAMA 289(19) (2003) 2560. - 2. CARRETERO O, OPARIL S, Circulation, 101 (2000) 329 - 3. Luft FC, J Hypertens, 16 (1998)1871. - 4. INTERSALT CO-OPERATIVE RESEARCH GROUP, J Hypertens,6(suppl. 4) (1988) S584. - 5. GELEIJNSE JM, KOK FJ, GROBBEE DE, European Journa of Public Health, 14 (2004)235. - 6. ROSE G, MARMOT MG, Br Heart J, 45 (1981)13. - 7. MARMOT MG, SHIPLEY MJ, ROSE G, Lancet, 1 (1984) 1003. - 8. KEIL JE, TYROLER HA, SANDIFER SH, Am J Public Health, 67(1977) 634. - 9. DISCHINGER PC, APOSTOLIDES AY, ENTWISLE G, J Chronic Dis, 34(1981) 405. - 10. KEIL JE, SANDIFER SH, LOADHOLT CB, Am J Public Health, 71(1981) 532. — 11. FORD ES, COOPER
RS, Hypertension, 18 (1991) 598. - 12. WAITZMAN NJ, SMITH KR, Am J Public Health, 84(1994) 945. - 13. VARGAS CM, INGRAM DD, GILLUM RF, Am J Epidemiol, 3 (2000)272. - 14. IVIČEVIĆ-UHERNIK A, VULETIĆ S, KERN J, DEČKOVIĆ-VUKRES V, MIHEL S, ERCEG M, PRISTAŠ I, Coll Antropol, 36 (Suppl 1) (2012) 3. - 15. GAUDEMARIS R, LANG T, CHATELLIER G, LARABI L, LAUWERS-CANCÈS V, MAÎTRE A, DIÈNE E, Hypertension, 39 (2002) 1119. — 16. BRUNER E, BMJ, 314 (1997) 1472. - 17. PHELAN J, LINK B, Journals of Gerontology. Series B, Psychological Sciences and Social Sciences 60 (2005) 27. - 18. MECHANIC D, Milbank Quarterly, 85 (2005) 533.

\section{Erceg}

Croatian National Institute of Public Health, Rockefellerova 7, 10000 Zagreb, Croatia e-mail: marijan.erceg@hzjz.hr

\section{POSTOJI LI POVEZANOST KRVNOG TLAKA I RAZINE OBRAZOVANJA? CroHort STUDIJA}

\section{S A Ž E T A K}

U radu su analizirani podaci za kohortu 1383 ispitanika u dobi 18+ iz Hrvatske kohortne studije kardiovaskularnog zdravlja prikupljeni tijekom intervjua provedenih tijekom 2003. i ponovljenih u 2008. godini. Cilj istraživanja bio je utvrditi kumulativnu petogodišnju incidenciju arterijske hipertenzije (dalje 5-CIAH) i njezinu zavisnost sprema edukaciji, tjelesnoj masi, dobi i spolu. Istraživanje je provedeno na kohorti ispitanika s početno normalnim arterijskim tlakom 
(sistolički < $140 \mathrm{mmHg}$ i dijastolički < $90 \mathrm{mmHg}$ i ne uzima lijekove). Podaci su prikupljani metodom strukturiranog intervjua te antropometrijskim mjerenjima (visina, težina, krvni tlak). Krvni tlak izmjeren je dva puta tijekom istog posjeta i izračunat prosjek za svakog ispitanika. Rezultati su iskazani postotcima 5-CIAH te njihovim 95\% intervalima pouzdanosti (dalje [ ]). Pored metoda deskriptivne statistike korišteni su $\chi^{2}$ test, te logistička regresija. Za statističku analizu korišten je statistički paket SPSS. U skupini muškaraca nije utvrđena povezanost edukacije i razvoja hipertenzije. U skupni žena u dobi 18-64 godine, normalne tjelesne mase, zabilježene su značajno više vrijednosti kumulativne incidencije arterijske hipertenzije u onih s manje od 12 godina školovanja (32,5\% [22,0 to 42,9]) u odnosu na one s 12 i više godina škole $(9,6 \%$ [6,1 to 13,1]). U skupini onih s prekomjernom tjelesnom masom te razlike nisu zabilježene. Povezanost edukacije i razvoja arterijske hipertenzije nije utvrđena u ispitanika starijih od 65 godina. 